\title{
Application of Ti-in-zircon thermometry to granite studies: problems and possible solutions
}

\author{
David Schiller $^{1} \cdot$ Fritz Finger $^{1}$
}

Received: 18 January 2019 / Accepted: 10 May 2019 / Published online: 27 May 2019

(c) The Author(s) 2019

\begin{abstract}
The application of the Ti-in-zircon thermometer to granitic rock requires consideration of $a_{\mathrm{TiO}_{2}}$ and $a_{\mathrm{SiO}_{2}}$ during zircon crystallization. Thermodynamic software programs such as rhyolite-MELTS or Perple_X permit the estimation of $a_{\mathrm{TiO}_{2}}$ and $a_{\mathrm{SiO}_{2}}$ values from whole-rock geochemical data as a function of pressure and temperature. Model calculations carried out on a set of 14 different granite types at $2 \mathrm{kbar}, 5 \mathrm{kbar}$, and $\mathrm{H}_{2} \mathrm{O}=3 \mathrm{wt} \%$ show $a_{\mathrm{SiO}_{2}}$ during zircon crystallization close to 1 $(0.75-1)$ and $a_{\mathrm{TiO}_{2}}$ generally far below unity (0.1-0.6). This would suggest that Ti-in-zircon temperatures for granites must be significantly upward corrected relative to the original $\mathrm{TiO}_{2}$ - and $\mathrm{SiO}_{2}$-saturated calibration of the thermometer. Both the rhyolite-MELTS and Perple_X calculations indicate that $a_{\mathrm{TiO}_{2}}$ is typically around 0.5 in ilmenite-bearing granites. Thus, for ilmenite-series granites (that is, almost all S-type and many I-type granites), it could be a reasonable first order approximation to apply a constant temperature correction of $+70{ }^{\circ} \mathrm{C}$ to the Ti-in-zircon thermometer. Granites lacking the paragenesis zircon-ilmenite, that is, some A-type granites and a few special I-type granites may have even lower $a_{\mathrm{TiO}_{2}}(0.1-0.5)$ and some of them may require a huge upward correction of Ti-in-zircon temperatures on the order of 100-200 ${ }^{\circ} \mathrm{C}$. Using a set of Tiin-zircon measurements from a Variscan granite of the Bohemian Massif, we introduce a novel $T$-dependent $a_{\mathrm{TiO}_{2}}$ and $a_{\mathrm{SiO}_{2}}$ correction of Ti-in-zircon calculated temperatures which is based on $a_{\mathrm{TiO}_{2}}{ }^{-}, a_{\mathrm{SiO}_{2}}-T$ functions modelled with rhyolite-MELTS. This method takes into account that early and late zircons in granitic systems may crystallize at different $a_{\mathrm{SiO}_{2}}$ and $a_{\mathrm{TiO}_{2}}$. Furthermore, we highlight the usefulness of comparing the corrected results of Ti-in-zircon thermometry with bulk-rock-Zrbased zircon solubility thermometry and ideal zircon crystallization temperature distributions for granites, and we present a graphical method that enables this comparison. In addition, this paper addresses the problem that Ti-in-zircon measurements are commonly collected with only moderate spatial analytical resolution, which leads to an averaging effect and to difficulties in recording accurate crystallization temperatures. Therefore, we propose that Ti-in-zircon thermometry for granites should generally rely on the more representative median- $T\left(T_{\text {med }}\right)$ value of a series of zircon analyses. Peak magma temperatures will be, in general, $35-50^{\circ} \mathrm{C}$ above $T_{\text {med }}$, as can be modelled using zircon crystallization temperature distributions.
\end{abstract}

Keywords Ti-in-zircon thermometry $\cdot$ Granite petrology $\cdot \mathrm{TiO}_{2}$ activity $\cdot$ Zircon saturation

\section{Introduction}

Communicated by Mark S Ghiorso.

David Schiller

david.schiller@stud.sbg.ac.at

Fritz Finger

friedrich.finger@sbg.ac.at

1 Department Chemistry and Physics of Materials, University of Salzburg, Jakob-Haringer-Strasse 2a, 5020 Salzburg, Austria
The Ti-in-zircon thermometer (Watson et al. 2006) could become a most interesting petrological tool for research on granitic rocks if we succeed to overcome a few ongoing problems. The thermometer is based on the temperaturedependent exchange reaction:

$\mathrm{ZrSiO}_{4}+\mathrm{TiO}_{2}=\mathrm{ZrTiO}_{4}+\mathrm{SiO}_{2}(\mathrm{~A})$.

A phase equilibrium investigation of the system "zircon + rutile + silicate melt/hydrothermal solution" at $1 \mathrm{GPa}$ (Ferry and Watson 2007) gives the amount of Ti in zircon as a function of temperature as: 
$\log (\mathrm{ppm} \mathrm{Ti})=5.711 \pm 0.072-\frac{4800( \pm 86)}{T(\mathrm{~K})}$.

While the thermometer is ideally suited for rocks that carry cogenetic zircon, rutile, and quartz (e.g., high-pressure granulites), its application to granites is not straightforward. First, most granites lack rutile implying that $a_{\mathrm{TiO}_{2}}$ must have been below unity when the zircons formed. Second, although granites are $\mathrm{SiO}_{2}$-rich, $a_{\mathrm{SiO}_{2}}$ can be below unity during early zircon crystallization, because quartz is normally not present at near liquidus conditions (Johannes and Holtz 1991). An equation that corrects the Ti-in-zircon thermometer for the effects of reduced $a_{\mathrm{TiO}_{2}}$ and $a_{\mathrm{SiO}_{2}}$ is given by Ferry and Watson (2007):

$$
\begin{aligned}
\log (\text { ppm Ti }) & =5.711 \pm 0.072-\frac{4800( \pm 86)}{T(\mathrm{~K})} \\
& -\log \left(a_{\mathrm{SiO}_{2}}\right)+\log \left(a_{\mathrm{TiO}_{2}}\right) .
\end{aligned}
$$

Initially, Ferry and Watson (2007) supposed $a_{\mathrm{TiO}_{2}}$ to be typically between 0.6 and 0.9 and only rarely below 0.5 in rocks lacking rutile at magmatic temperatures. Further investigations have documented that volcanic rocks with $a_{\mathrm{TiO}_{2}} \sim 0.5$ may be quite common (Hayden and Watson 2007; Vazquez et al. 2009; Reid et al. 2011; Ghiorso and Gualda 2012), but systematic study on the variation of $a_{\mathrm{SiO}_{2}}$ and $a_{\mathrm{TiO}_{2}}$ in magmatic rocks has not been done so far. We will present such a study in this paper, using the thermodynamic software programs rhyolite-MELTS (Gualda et al. 2012) and Perple_X (Conolly and Petrini 2002). Our results clearly suggest that Ti-in-zircon temperatures for granites have to be significantly upward corrected relative to the original $\mathrm{TiO}_{2}$ and $\mathrm{SiO}_{2}$-saturated calibration of the thermometer, due to generally low $a_{\mathrm{TiO}_{2}}$. In addition, we emphasize that zircon crystallization in a granite typically takes place over a larger temperature interval of $80-100{ }^{\circ} \mathrm{C}$ (Ickert et al. 2011) and that $a_{\mathrm{SiO}_{2}}$ and $a_{\mathrm{TiO}_{2}}$ can potentially change when the magma temperature falls. Therefore, we introduce a new method for a $T$-dependent $a_{\mathrm{SiO}_{2}}$ and $a_{\mathrm{TiO}_{2}}$ correction of Ti-in-zircon thermometry data.

During this study, we realized that it is highly advantageous to combine Ti-in-zircon thermometry with $\mathrm{Zr}$ solubility calculations (Watson and Harrison 1983) and we present a diagram that allows both datasets to be effectively compared. Inconsistency between results from the two thermometers indicates that analytical or methodological complications (Siegel et al. 2018) are at play. Furthermore, we highlight a few additional methodological problems, which often arise when Ti-in-zircon thermometry is applied to granites, and we discuss possible solutions.

\section{Methodological approach}

\section{Thermodynamic modeling}

Rhyolite-MELTS (Gualda et al. 2012) and Perple_X (Conolly and Petrini 2002) are thermodynamic calculation software which work by minimization of the Gibb's free energy for a given bulk rock, pressure, and temperature. The stable phases, their amounts (as percentage), and specific compositions are then calculated for a given $P-T$ range. Both software programs require whole-rock geochemistry data as an input. Care must be taken that $\mathrm{Fe}_{2} \mathrm{O}_{3}$ and $\mathrm{FeO}$ are independently determined. Mineral buffers can be used instead of fixed $\mathrm{Fe}^{2+} / \mathrm{Fe}^{3+}$ ratios if there are concerns that the $\mathrm{Fe}^{2+} / \mathrm{Fe}^{3+}$ ratios received alteration at subsolidus conditions. According to our experience, the $\mathrm{C}-\mathrm{COH}$ and QFM buffers give good results for ilmeniteseries granites (Ishihara 1977) and for magnetite-series granites, respectively.

We used a water content of $3 \mathrm{wt} \%$ for all our calculations, as this is considered a realistic value for many granitic magmas (Clemens and Vielzeuf 1987). We also found that varying the amount of water did not significantly change the calculated activities.

Neither rhyolite-MELTS nor Perple_X provide $a_{\mathrm{TiO}_{2}}$ and $a_{\mathrm{SiO}_{2}}$ values directly. These must be further calculated from affinity and chemical potential values output from rhyolite-MELTS and Perple_X, respectively. According to Ghiorso and Gualda (2012), the $\mathrm{TiO}_{2}$ affinity value $\left(a_{\mathrm{TiO}_{2}}\right)$, as obtained from rhyolite-MELTS, can be directly transformed into an activity $\left(a_{\mathrm{TiO}_{2}}\right)$ value using the equation:

$a_{\mathrm{TiO}_{2}}=\mathrm{e}^{\left(\frac{-{ }_{\mathrm{A}} \mathrm{TiO}_{2}}{R \cdot T}\right)}$,

where $R$ is the gas constant $\left(\mathrm{J} \mathrm{mol}^{-1} \mathrm{~K}^{-1}\right)$ and $T$ is the temperature (K).

The same holds true for $\mathrm{SiO}_{2}$. In case of Perple_X, the activity value can be calculated from chemical potential $\left(\mu_{\mathrm{TiO}_{2}}\right)$ and the Gibbs free enthalpy of rutile $\left(G_{\mathrm{TiO}_{2}}\right)$ values using the equation:

$a_{\mathrm{TiO}_{2}}=\mathrm{e}^{-\left(\frac{G_{\mathrm{TiO}}^{P}-\mu_{\mathrm{TiO}}^{P T}}{R \cdot T}\right)}$

For Perple_X, the following mixing models were used: orthopyroxene, clinopyroxene, biotite, and melt (Powell and Holland 1999); feldspar (Benisek et al. 2010); ilmenite; and magnetite (Andersen and Lindsley 1988). Perple_X has the disadvantage that it does not consider the solubility of $\mathrm{Ti}$ in a granitic melt. 


\section{Zircon solubility thermometry}

Three models are available (Watson and Harrison 1983; Boehnke et al. 2013, Gervasoni et al. 2016); however, studies have shown they yield slightly different results (see Gervasoni et al. 2016 for comparison of the models). For this study, we preferred the model of Watson and Harrison (1983), because the temperature results appear to be more consistent with granitic melting experiments. For a haplogranitic melt near the ternary minimum $\left(680{ }^{\circ} \mathrm{C}\right.$ at $200 \mathrm{MPa}$ water pressure; Johannes and Holtz 1991), the $\mathrm{Zr}$ solubility would be $\sim 40 \mathrm{ppm}$ according to Watson and Harrison (1983), 83 ppm according to Boehnke et al. (2013) and $~ 95$ ppm according to Gervasoni et al. (2016). Very-low$\mathrm{T}$ granites with near minimum melt compositions (including fractionated and unfractionated subtypes-see Finger and Schiller 2012) commonly have $\mathrm{Zr}$ contents around $40 \mathrm{ppm}$ and even lower (e.g., Williamson et al. 1996; Nabelek et al. 1992). This matches best with the Watson and Harrison's (1983) model.

According to Watson and Harrison (1983), the relationship between $T$ and the amount of dissolved $\mathrm{Zr}$ in a $\mathrm{Zr}$-saturated silicate melt is:

$\ln D^{\text {Zircon/Melt }}=-3.8-[0.85(M-1)]+\frac{12900}{T}$,

with $M$ being a composition parameter given by the (molecular) ratio:

$M=\frac{x_{\mathrm{Na}}+x_{\mathrm{K}}+2 x_{\mathrm{Ca}}}{x_{\mathrm{Si}} \cdot x_{\mathrm{Al}}}$.

Using Eq. (5) in combination with crystallization modeling by rhyolite-MELTS allows ideal magmatic zircon crystallization curves ( $T$ vs. zircon crystallization rate) to be calculated from whole-rock geochemistry data (Harrison et al. 2007; Ickert et al. 2011; Burke 2017). The calculation procedure is not trivial, because the decreasing melt proportion during granite crystallization has to be taken into account. In addition, $M$ values do not remain constant. The approach recommended here is to initially model the major mineral crystallization history of the granite under study in steps of $10{ }^{\circ} \mathrm{C}$ by means of rhyolite-MELTS, monitoring both the melt proportion and its melt composition. The amount of dissolved $\mathrm{Zr}$ in the melt can then be calculated for every temperature step using the Watson and Harrison's (1983) model, and these data points can finally be fitted by a logarithmic function. In combination with the $\mathrm{Zr}$ whole-rock data, $T$ at which the first (autocrystic) zircon will ideally form in a given granite $\left[T_{\mathrm{Zr}(M)}\right]$, and $T$ at which 10,20 , or $50 \%$ of the zirconium will have crystallized as zircon (assuming that zircon is the only $\mathrm{Zr}$ carrier mineral and that all $\mathrm{Zr}$ was initially dissolved in the melt phase) can be obtained. Note that
$T_{\mathrm{Zr}(M)}$ can be higher than the $T_{\mathrm{Zr}}$ saturation value of Watson and Harrison (1983) if a magma contains larger amounts of a restitic (or peritectic) major mineral component. Ideally, the theoretical zircon crystallization curve of a granite ( $T$ vs. percent of crystallized zircons) should be identical to the measured range of Ti-in-zircon temperatures (Ickert et al. 2011).

In conjunction with $a_{\mathrm{TiO}_{2}}-$ and $a_{\mathrm{SiO}_{2}}-T$ functions derived from rhyolite-MELTS or Perple_X, a detailed, $T$-dependent, $a_{\mathrm{TiO}_{2}}$ and $a_{\mathrm{SiO}_{2}}$ correction of Ti-in-zircon temperatures can be made that is particularly useful for granites, where $a_{\mathrm{TiO}_{2}}$ and $a_{\mathrm{SiO}_{2}}$ potentially changed during zircon crystallization.

To begin, we use a set of Ti contents measured in zircons from the Strážný granite from the South Bohemian Batholith to highlight the $a_{\mathrm{TiO}_{2}}$ and $a_{\mathrm{SiO}_{2}}$ issue and to introduce our methodological approach. Subsequently, we undertake a broader analysis of the variation of $a_{\mathrm{SiO}_{2}}$ and $a_{\mathrm{TiO}_{2}}$ in granitic systems, as a function of magma composition, $P$ and $T$, based on different published granite compositions.

\section{The Strážný granite}

\section{Zircon analysis results and uncorrected Ti-in-zircon temperatures}

The set of LA-ICP-MS zircon analyses, which are presented here, was obtained on a handpicked, slightly ground and polished zircon grain mount from a granite sample from the Strážný Massif in the Czech part of the South Bohemian Batholith (Klomínský et al. 2010; Žák et al. 2014). The investigated granite belongs to the weakly peraluminous, I/S-transitional Weinsberg granite suite of the South Bohemian Batholith (Frasl and Finger 1991), which formed by fluid-absent melting of biotite-quartz-plagioclase assemblages in the lower crust, at temperatures between 850 and $900{ }^{\circ} \mathrm{C}$ (Finger and Clemens 1995). The Weinsberg granite of the Strážný Massif (termed here the Strážný granite) is a coarse-grained biotite granite with porphyritic K-feldspars of up to $5 \mathrm{~cm}$ length. Accessory minerals include ilmenite, apatite, monazite, and zircon. The $\mathrm{SiO}_{2}$ content of the Strážný granite varies between 65 and $73 \mathrm{wt} \%$. The granite is slightly peraluminous, alkali-calcic, and ferroan (Frost et al. 2001).

The zircon analyses were carried out at Boise University, using a Thermo-Electron X-Series II quadrupole ICPMS and a New Wave Research UP-213 Nd:YAG UV $(213 \mathrm{~nm})$ laser ablation system. Fifty-four zircon grains were targeted with a spot size of $\sim 25 \mu \mathrm{m}$. The analysis protocol followed Rivera et al. (2013) and was specifically designed to capture trace-element concentrations, Tiin-zircon concentrations for thermometry, and $\mathrm{U}-\mathrm{Th}-\mathrm{Pb}$ isotope ratios within the same spot analysis. Dwell times 
were $5 \mathrm{~ms}$ for $\mathrm{Si}$ and $\mathrm{Zr}$; $100 \mathrm{~ms}$ for ${ }^{49} \mathrm{Ti}$ and ${ }^{207} \mathrm{~Pb}, 40 \mathrm{~ms}$ for ${ }^{238} \mathrm{U},{ }^{232} \mathrm{Th},{ }^{202} \mathrm{Hg},{ }^{204} \mathrm{~Pb},{ }^{206} \mathrm{~Pb}$, and ${ }^{208} \mathrm{~Pb}$ isotopes and $10 \mathrm{~ms}$ for all other HFSE and REE elements, for a total sweep time of $750 \mathrm{~ms}$. A $60 \mathrm{~s}$ analysis $(15 \mathrm{~s}$ gas blank, $45 \mathrm{~s}$ ablation with $5 \mathrm{~Hz}$ laser pulse and $14 \mathrm{~J} \mathrm{~cm}^{-2}$ fluence) excavated a pit approximately $25 \mu \mathrm{m}$ deep. Background count rates for each analyte were obtained prior to each spot analysis and subtracted from the raw count rates. For concentration calculations, average background-subtracted count rates for each analyte were internally normalized to ${ }^{29} \mathrm{Si}$, and calibrated with respect to the primary standards NIST SRM-610 and SRM-612 glasses. Secondary standards included USGS BIR-1 and BCR-2 glasses and the AUS-Z2 zircon megacryst (Kennedy 2011). The analytical point error is better than $1 \mathrm{ppm}$ for Ti which is equivalent to $\pm 10{ }^{\circ} \mathrm{C}$.

Table 1 shows the range of Ti contents that were measured in the zircon crystals. They vary from 2.5 to $17.3 \mathrm{ppm}$ and correspond to uncorrected Ti-in-zircon temperatures of $629-800{ }^{\circ} \mathrm{C}$ (excluded from Table 1 are 11 analyses of non-autocrystic zircon cores with old U-Pb ages). A geochemical analysis of the granite sample KV829 is given in Table 2. The whole-rock $\mathrm{Zr}$ content is $309 \mathrm{ppm}$ and corresponds to a zircon saturation temperature $\left(T_{\mathrm{Zr}}\right)$ of $841{ }^{\circ} \mathrm{C}$ (Watson and Harrison 1983). Overall, a negative $\mathrm{SiO}_{2}-\mathrm{Zr}$ covariation is seen in the whole-rock data for the Strážný granite. Thus, complete $\mathrm{ZrSiO}_{4}$ saturation can be assumed during magmatic crystallization (Chappell et al. 1998; Kemp et al. 2005), which is consistent with the preservation of inherited zircon. $T_{\mathrm{Zr}}$ should, thus, give an estimate of the peak magma temperature. However, the presence of older zircons should also be taken into account in the peak temperature estimation. From the measured $\mathrm{U}-\mathrm{Pb}$ ages, we estimated that there is $<10 \%$ older zircon, which is equivalent to a reduction of the $\mathrm{Zr}$-saturation temperature of $\leq 7{ }^{\circ} \mathrm{C}$, which is considered insignificant.

According to rhyolite-MELTS, sample KV829 was not fully molten at $T_{\mathrm{Zr}}$ with an assumed bulk content of $3 \%$ $\mathrm{H}_{2} \mathrm{O}$. The minerals at this stage are given as oligoclase, ortho-pyroxene, ilmenite, and magnetite. As these phases do not incorporate appreciable amounts of $\mathrm{Zr}$, and taking into account the reduced amount of melt $(87 \%), T_{\mathrm{Zr}}$ must be slightly upward corrected from 841 to $850{ }^{\circ} \mathrm{C}\left(T_{\mathrm{Zr}(M)}\right)$. Independent of these minor uncertainties, we note that the zircon saturation model gives a much higher temperature than the uncorrected Ti-in-zircon thermometer (Table 1). Even the highest obtained Ti-in-zircon $T$ value of $800{ }^{\circ} \mathrm{C}$ (analysis 1 in Table 1 ) remains $\sim 50{ }^{\circ} \mathrm{C}$ below $T_{\operatorname{Zr}(M)}$.

\section{Calculation of $a_{\mathrm{TiO}_{2}}$ and $a_{\mathrm{SiO}_{2}}$}

Like most granites, the studied sample KV829 does not contain rutile. The major Ti-carrier minerals identified in thin section are ilmenite and biotite. The rhyolite-MELTS software indicates the following crystallization sequence for the rock at $2 \mathrm{kbar}$ and a water content of $3 \mathrm{wt} \%$ : 7\% plagioclase, $5 \%$ orthopyroxene, $0.5 \%$ magnetite, $0.5 \%$ ilmenite at $850{ }^{\circ} \mathrm{C}$, K-feldspar-in at $783{ }^{\circ} \mathrm{C}$, and quartz-in at $760{ }^{\circ} \mathrm{C}$. As stated in Gualda et al. (2012), biotite is not dependably modelled by rhyolite-MELTS. In our calculation, biotite does not occur above the solidus, although magmatic biotite is obviously present in the sample. We will discuss these issue in Sect. 5.1.

Transforming the $\mathrm{TiO}_{2}$ affinity values, as obtained from rhyolite-MELTS, into activity values (Eq. 3), we get $a_{\mathrm{TiO}_{2}}=0.42$ at $850{ }^{\circ} \mathrm{C}$ and $a_{\mathrm{TiO}_{2}}=0.44$ at $750{ }^{\circ} \mathrm{C}$. The $a_{\mathrm{TiO}_{2}}$ $-T$ function is shown in Fig. 1 . An attempt to model $a_{\mathrm{TiO}_{2}}$ independently with Perple_X leads to a very similar result (Fig. 1). The relatively low $\mathrm{TiO}_{2}$ activity values of $0.4-0.5$, which are indicated by both software programs, would necessitate a significant upward correction of Ti-in-zircon temperatures, in the order of $80{ }^{\circ} \mathrm{C}$. The Ti-in-zircon temperatures would then be shifted into a range that is very consistent with the zircon saturation temperature (Table 1).

Quartz crystallizes late in the paragenesis of sample KV829 (quartz-in at $\sim 760^{\circ} \mathrm{C}$ ). Therefore, the $a_{\mathrm{SiO}_{2}}$ values will remain below unity over a large part of the magmatic zircon crystallization range. Figure 1 shows the variation of $a_{\mathrm{SiO}_{2}}$ as a function of $T$. According to rhyolite-MELTS, $a_{\mathrm{SiO}_{2}}$ steadily increases with falling temperature from $\sim 0.88$ at $850{ }^{\circ} \mathrm{C}$ to $\sim 0.95$ at $800{ }^{\circ} \mathrm{C}$ before reaching unity at $760{ }^{\circ} \mathrm{C}$ (quartz-in). The Perple_X calculation gives a similar result (Fig. 1). The $a_{\mathrm{SiO}_{2}}$ correction effect on the Ti-in-zircon temperatures can be taken from Table 1. The highest $T$ zircons require the largest correction of $10-20^{\circ} \mathrm{C}$, but this is significantly less than the $a_{\mathrm{TiO}_{2}}$-correction (Table 1).

\section{A useful test: comparing the Ti-in-zircon temperature range of a granite with its ideal magmatic zircon crystallization temperature distribution curve}

Figure 2a shows the "zircon crystallization temperature distribution" (ZCTD) (Ickert et al. 2011) for sample KV829 as modelled on the basis of geochemistry, in synopsis with the corrected and uncorrected Ti-in-zircon temperatures (arranged by decreasing temperature). It can be seen that the $a_{\mathrm{TiO}_{2}}$ and $a_{\mathrm{SiO}_{2}}$ corrections have shifted the Ti-in-zircon temperatures into a range that is consistent with the zircon crystallization model of Watson and Harrison (1983).

The peak temperature of a granitic magma is commonly of greatest interest for magmatic petrology. However, its direct determination using Ti-in-zircon thermometry is difficult. The highest measured Ti content in magmatic (autocrystic) zircon should give this peak temperature (Siégel et al. 2018). However, it is inherently difficult to 
Table 1 Ti contents measured in zircons from sample KV-829 and Ti-in-zircon temperatures calculated according to Ferry and Watson (2007)

\begin{tabular}{|c|c|c|c|c|c|c|c|}
\hline \multirow[t]{2}{*}{ Grain } & \multirow[t]{2}{*}{$\mathrm{Ti}(\mathrm{ppm})$} & \multirow[t]{2}{*}{$T\left({ }^{\circ} \mathrm{C}\right)$ uncorr. } & \multirow{2}{*}{$\begin{array}{l}T\left({ }^{\circ} \mathrm{C}\right) \text { cor- } \\
\text { rected }\end{array}$} & \multicolumn{4}{|c|}{ Correction parameters/temperature effect } \\
\hline & & & & $a_{\mathrm{SiO}_{2}}$ & $\left({ }^{\circ} \mathrm{C}\right)$ & $a_{\mathrm{TiO}_{2}}$ & $\left({ }^{\circ} \mathrm{C}\right)$ \\
\hline 1 & 17.3 & 800 & 880 & $0.84(-18)$ & & $0.41(+101)$ & \\
\hline 2 & 13.4 & 774 & 853 & $0.87(-13)$ & & $0.42(+94)$ & \\
\hline 3 & 12.3 & 766 & 845 & $0.89(-12)$ & & $0.42(+92)$ & \\
\hline 4 & 12.0 & 763 & 842 & $0.89(-11)$ & & $0.42(+92)$ & \\
\hline 5 & 11.8 & 761 & 840 & $0.89(-11)$ & & $0.42(+91)$ & \\
\hline 6 & 11.6 & 760 & 838 & $0.89(-11)$ & & $0.42(+91)$ & \\
\hline 7 & 11.1 & 756 & 834 & $0.90(-10)$ & & $0.42(+90)$ & \\
\hline 8 & 10.3 & 748 & 826 & $0.91(-9)$ & & $0.42(+88)$ & \\
\hline 9 & 10.2 & 748 & 826 & $0.91(-9)$ & & $0.42(+88)$ & \\
\hline 10 & 9.9 & 745 & 823 & $0.92(-8)$ & & $0.42(+87)$ & \\
\hline 11 & 9.9 & 745 & 823 & $0.92(-8)$ & & $0.42(+87)$ & \\
\hline 12 & 9.7 & 743 & 820 & $0.92(-8)$ & & $0.42(+87)$ & \\
\hline 13 & 9.6 & 742 & 819 & $0.92(-8)$ & & $0.42(+87)$ & \\
\hline 14 & 9.4 & 741 & 818 & $0.92(-8)$ & & $0.43(+86)$ & \\
\hline 15 & 9.4 & 740 & 818 & $0.92(-7)$ & & $0.43(+86)$ & \\
\hline 16 & 9.4 & 740 & 818 & $0.92(-7)$ & & $0.43(+86)$ & \\
\hline 17 & 9.4 & 740 & 817 & $0.92(-7)$ & & $0.43(+86)$ & \\
\hline 18 & 9.3 & 739 & 816 & $0.92(-7)$ & & $0.43(+86)$ & \\
\hline 19 & 9.3 & 739 & 816 & $0.92(-7)$ & & $0.43(+86)$ & \\
\hline 20 & 8.7 & 733 & 810 & $0.93(-6)$ & & $0.43(+84)$ & \\
\hline 21 & 8.6 & 732 & 808 & $0.93(-6)$ & & $0.43(+84)$ & \\
\hline 22 & 8.6 & 732 & 808 & $0.93(-6)$ & & $0.43(+84)$ & \\
\hline 23 & 8.5 & 731 & 808 & $0.93(-6)$ & & $0.43(+84)$ & \\
\hline 24 & 8.5 & 731 & 808 & $0.94(-6)$ & & $0.43(+84)$ & \\
\hline 25 & 8.5 & 731 & 807 & $0.94(-6)$ & & $0.43(+84)$ & \\
\hline 26 & 8.4 & 730 & 807 & $0.94(-6)$ & & $0.43(+84)$ & \\
\hline 27 & 8.4 & 730 & 807 & $0.94(-6)$ & & $0.43(+84)$ & \\
\hline 28 & 8.2 & 728 & 804 & $0.94(-6)$ & & $0.43(+83)$ & \\
\hline 29 & 8.0 & 725 & 802 & $0.94(-5)$ & & $0.43(+83)$ & \\
\hline 30 & 7.6 & 721 & 797 & $0.95(-5)$ & & $0.43(+82)$ & \\
\hline 31 & 7.6 & 721 & 797 & $0.95(-5)$ & & $0.43(+82)$ & \\
\hline 32 & 7.0 & 713 & 789 & $0.96(-4)$ & & $0.43(+80)$ & \\
\hline 33 & 6.8 & 711 & 787 & $0.96(-3)$ & & $0.43(+80)$ & \\
\hline 34 & 6.6 & 709 & 784 & $0.97(-3)$ & & $0.43(+79)$ & \\
\hline 35 & 6.4 & 706 & 782 & $0.97(-3)$ & & $0.43(+78)$ & \\
\hline 36 & 6.3 & 704 & 779 & $0.97(-2)$ & & $0.43(+78)$ & \\
\hline 37 & 6.0 & 701 & 776 & $0.98(-2)$ & & $0.43(+77)$ & \\
\hline 38 & 5.4 & 691 & 765 & $0.99(-1)$ & & $0.44(+75)$ & \\
\hline 39 & 5.3 & 690 & 764 & $0.99(-1)$ & & $0.44(+75)$ & \\
\hline 40 & 5.3 & 689 & 763 & $0.99(-1)$ & & $0.44(+75)$ & \\
\hline 41 & 4.1 & 668 & 739 & $1.00(0)$ & & $0.44(+71)$ & \\
\hline 42 & 4.0 & 666 & 736 & $1.00(0)$ & & $0.44(+70)$ & \\
\hline 43 & 2.5 & 629 & 692 & $1.00(0)$ & & $0.45(+63)$ & \\
\hline
\end{tabular}

accurately measure the maximum and minimum Ti content of a magmatic zircon population by current, commonly used zircon analysis techniques due to insufficient spatial resolution (Ickert et al. 2011). Ti concentrations in zircon are normally measured using an ion probe or a Laser-ICP-MS with 20-30 $\mu \mathrm{m}$ measuring spot sizes. Although accessory zircons in granites are commonly 50-200 $\mu \mathrm{m}$ in size, they are generally internally finely zoned with early magmatic 


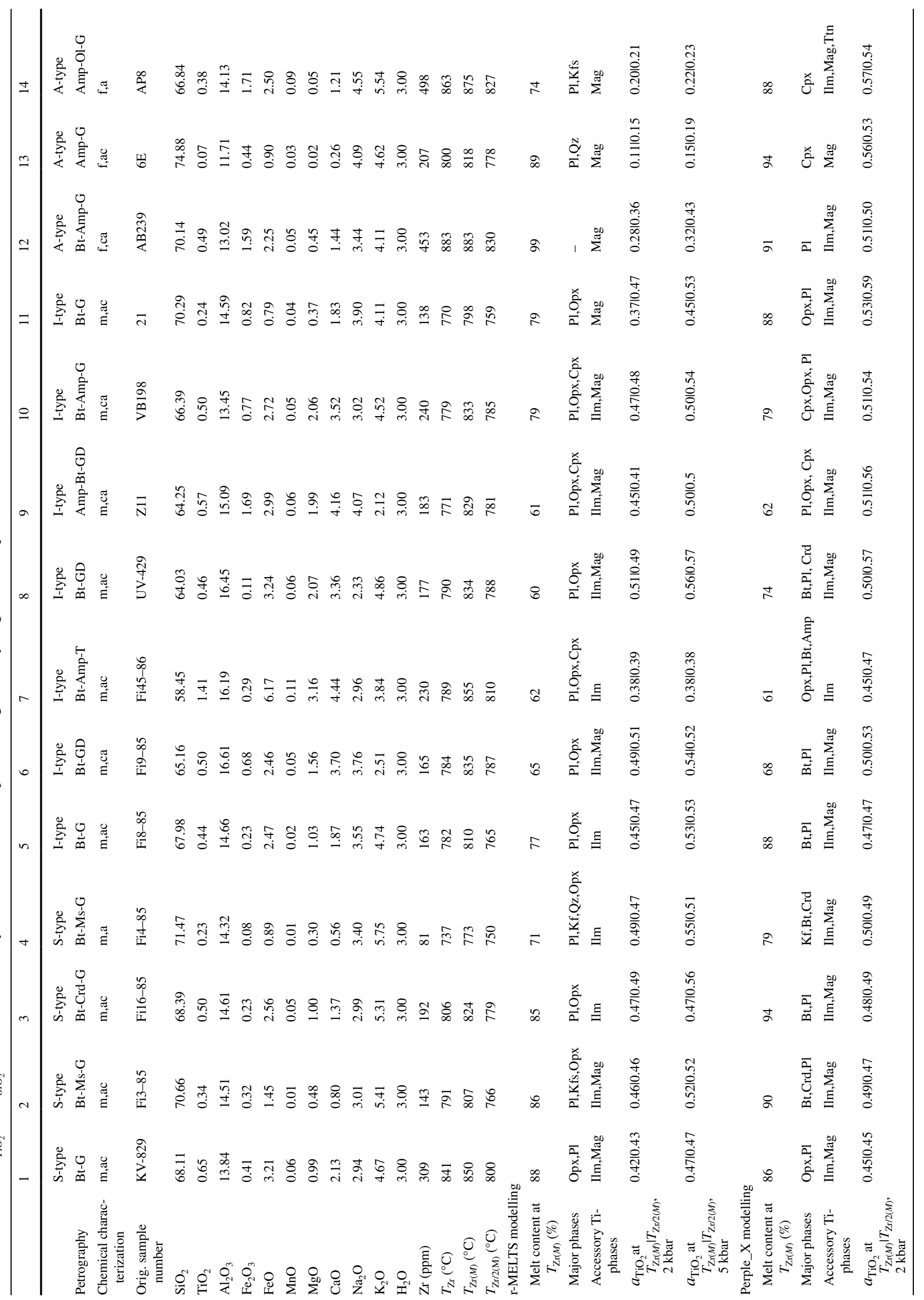




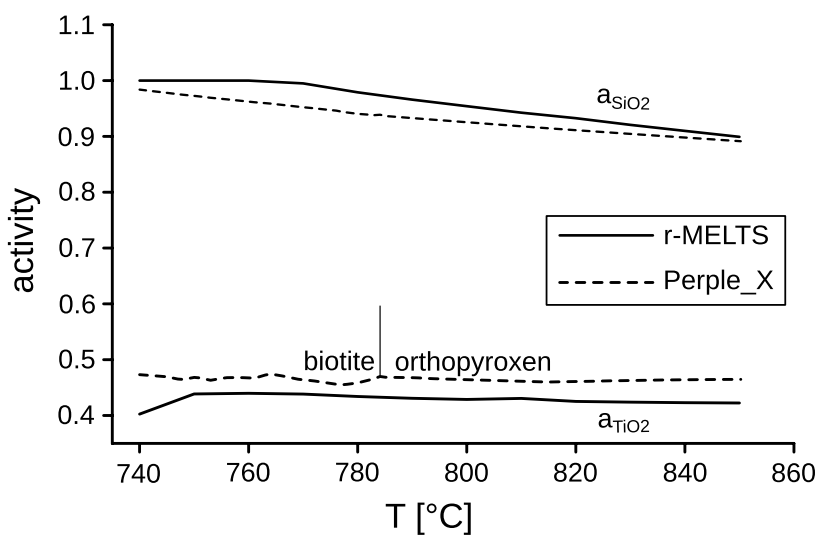

Fig. $1 a_{\mathrm{TiO}_{2}}$ and $a_{\mathrm{SiO}_{2}}$ vs. $T$ functions for granite KV829 as calculated with rhyolite-MELTS and Perple_X

high temperature cores and late-magmatic low-temperature rims (Ickert et al. 2011). Measuring these fine zones with $20-30 \mu \mathrm{m}$ spot sizes is fraught with difficulty. Thus, measured Ti amounts often contain some averaging effect; intermediate compositions and temperature data will be overrepresented.

The sigmoidal shape of the Ti-in-zircon temperature curve in Fig. 2a likely reflects a method-inherent sampling bias towards medium-T zircons. We have tried to replicate such a sampling bias effect with a model calculation. The ideal ZCTD for sample KV829 was used as starting situation and then adjusted using Gaussian probability models with different standard deviations. It can be seen that the original logarithmic curve is distorted to a sigmoidal shape in these models similar to the observed distribution (Fig. 2b).

Thus, instead of merely relying on the measured maximum Ti, users of the Ti-in-Zr thermometer should also try to estimate the peak magma temperature from the median Ti content of a zircon population, which is a more robust parameter. We propose here that the median Ti-in-zircon temperature ( $T_{\text {med }}$, i.e., the middle value of the temperature range) should be routinely reported in granite studies. Theoretically, exactly half (by mass) of a magmatic zircon population should have crystallized at $T_{\text {med }}$, and half of the zirconium is still dissolved in the melt fraction. The construction of an ideal "zircon crystallization temperature distribution" from whole-rock chemistry data (Fig. 3c) provides the means to estimate the maximum temperature of a granite melt from the $T_{\text {med }}$ value. Due to the logarithmic nature of the ZCTD, the difference between $T_{\text {med }}$ and $T_{\max }$ is constant for a given sample, independent of absolute $\mathrm{Zr}$ content or melt temperature, see Sect. 2 for the calculation procedure.

A comparison of measured Ti-in-zircon temperatures with the ZCTD curve of a sample can greatly help to recognize anomalous measurements from, for instance, antecrystic 

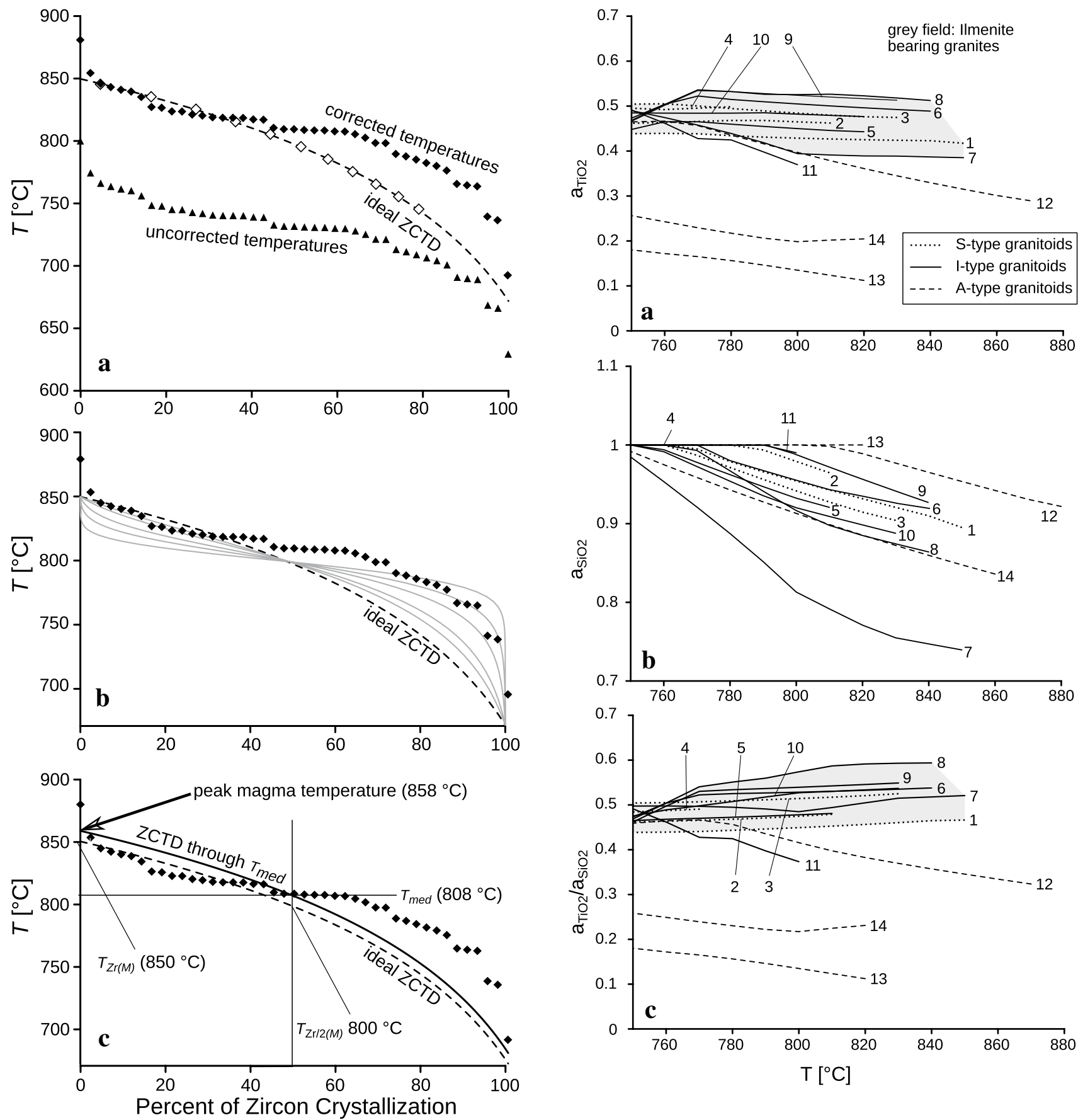

Fig. 2 a Ideal "zircon crystallization temperature distribution" (ZCTD) for sample KV829 in comparison with the measured Tiin-zircon temperatures (uncorrected vs. corrected values, using a $T$-dependent $a_{\mathrm{TiO}_{2}}$ and $a_{\mathrm{SiO}_{2}}$ correction routine-see Table 1). b Measured Ti-in-zircon temperatures for sample KV829 $\left(a_{\mathrm{TiO}_{2}}\right.$ and $a_{\mathrm{SiO}_{2}}$ corrected) in comparison with the ideal ZCTD and model curves (grey) that simulate an overrepresentation of average zircons (see text). c Measured Ti-in-zircon temperatures for sample KV829 and calculated $T_{\mathrm{Zr}(M)}-T_{\mathrm{Zr} / 2(M)}$ relations. A robust estimation of $T_{\max }$ (theoretical peak magma temperature in the case of zircon saturation) is possible by constructing a parallel curve to the ideal ZCTD through $T_{\text {med }}$, the intersection of which with the ordinate gives $T_{\max }$

Fig. $3 a_{\mathrm{SiO}_{2}}-T$ and $a_{\mathrm{TiO}_{2}}-T$ functions as calculated for different granite compositions with rhyolite-MELTS (numbers refer to granite analyses given in Table 2)

or xenocrystic zircons (Siégel et al. 2018; Claiborne et al. 2010) or simply bring to light inaccurate or contaminated analyses: For example, with respect to our case study (sample KV829, Table 1, Fig. 2), we observe that the highest measured $\mathrm{Ti}$ value $\left(17.3 \mathrm{ppm}, 880^{\circ} \mathrm{C}\right.$ after correction) is an outlier of unclear significance. It is possible that the laser beam hit a small Ti bearing inclusion, which was overlooked during data reduction. The second-highest Ti value 
(13.4 ppm; analysis 2 in Table 1) gives a temperature of $853^{\circ} \mathrm{C}$ and lies very close to the theoretical zircon crystallization curve.

\section{Modeling $a_{\mathrm{TiO}_{2}}-T$ and $a_{\mathrm{SiO}_{2}}-T$ functions for different granite types}

\section{Procedure and assumptions}

Granitic magmas (sensu lato) show considerable compositional variations in terms of their silica and alkali-element contents (Middlemost 1994), their peraluminousity and maficity (Chappell and White 1974, Clemens and Stevens 2012), and their $\mathrm{Fe} / \mathrm{Mg}$ and $(\mathrm{Na}+\mathrm{K}) / \mathrm{Ca}$ ratios (Frost et al. 2001). Our intention was to investigate, by means of rhyolite-MELTS and Perple_X, to what extent $a_{\mathrm{TiO}_{2}}$ and $a_{\mathrm{SiO}_{2}}$ values can vary in granitic systems as a function of magma composition. To this end, we have utilized the following selection of published granite data (numbers refer to Table 2; the designation of the rocks to the S-, I-, or A-type granite group is based on the original papers, which are cited below):

1-4: variably $\mathrm{SiO}_{2}$-rich, moderately to strongly peraluminous S-type granites from the Variscan South Bohemian Batholith (Liew et al. 1989; Fuchs and Thiele 1968).

5-8: various, medium-K to high-K, I-type granitoids (incl. granite, granodiorite, and tonalite) from the South Bohemian Batholith (Liew et al. 1989; Fuchs and Thiele 1968) and the Austrian Hohe Tauern Batholith (Finger and Steyrer 1988).

9: a volcanic-arc granodiorite (I-type) from the Zagros orogen in Iran (Alaminia et al. 2013).

10: fractionated biotite-amphibole granite from the Boggy Plain high-T, I-type suite (Wyborn et al. 1987; Chappell et al. 1998).

11: a magnetite-series, I-type granodiorite from the Tuolumne intrusive complex (Bateman and Chappell 1979).

12-14: three representatives of A-type granites from the Lachlan Fold belt (King et al. 1997), the Evisa complex in Corsica (Whalen et al. 1987), and the White Mountain Complex (Eby et al. 1992).

Zircon crystallization curves were constructed for all 14 granites following the procedure described in Sect. 2. The $T_{\mathrm{Zr} / 2}$ value in Table 2 gives the temperature, at which half of the whole-rock $\mathrm{Zr}$ content is still dissolved in the melt phase, i.e., after $50 \%$ of the zircons precipitated. For the sake of simplicity complete zircon saturation was assumed for all rocks, and any possible occurrence of non-autocrystic zircon was ignored, as these factors have no influence on the $a_{\mathrm{SiO}_{2}}$ and $a_{\mathrm{TiO}_{2}}$ estimates. Interestingly, the modeling suggests that appreciable amounts (1-39\%) of solid phases were present in nearly all of the granitoids at the estimated peak temperatures $\left[T_{\operatorname{Zr}(M)}\right.$ values in Table 2]. We would interpret this in terms of restite or peritectic phase contents (Chappell et al. 1987; Stevens et al. 2007; Clemens and Stevens 2012) or due to crystal accumulations.

\section{$a_{\mathrm{TiO}_{2}}$ values}

Using the rhyolite-MELTS software program, 10 of the 14 investigated granites are modelled to have crystallized in a surprisingly narrow $a_{\mathrm{TiO}_{2}}$ range of $0.5 \pm 0.1$. All these granites with $a_{\mathrm{TiO}_{2}} \sim 0.5$ (1-11 in Table 2 ) have in common that they contain ilmenite in the rhyolite-MELTS calculation. The $a_{\mathrm{TiO}_{2}}-T$ functions of these ilmenite-bearing granites are always flat (Fig. 3a), and the $a_{\mathrm{TiO}_{2}}$ values for $5 \mathrm{kbar}$ are only insignificantly higher than for $2 \mathrm{kbar}$ (Table 2).

The three A-type granite examples (12-14 in Table 2) and the I-type granite number 11 (a relatively strongly oxidized granite with $\mathrm{Fe}_{2} \mathrm{O}_{3}>\mathrm{FeO}$ ) give clearly lower $a_{\mathrm{TiO}_{2}}$ values of between 0.15 and 0.45 and are ilmenite free in the rhyoliteMELTS calculation at $T_{\mathrm{zr}(M)}$. Notably, the $a_{\mathrm{TiO}_{2}}-T$ functions of these four samples show a pronounced negative slope (Fig. 3a). The $a_{\mathrm{TiO}_{2}}$ values for $5 \mathrm{kbar}$ are again slightly higher than for 2 kbar (Table 2).

The calculation with Perple_X gives $a_{\mathrm{TiO}_{2}}$ values of $0.5-0.6$ for granites 1-11 (Table 2). These values are only slightly higher than the rhyolite-MELTS-based $a_{\mathrm{TiO}_{2}}$ values. However, importantly, Perple_X does not reproduce the low $a_{\mathrm{TiO}_{2}}$ values that were calculated with rhyolite-MELTS for granites 12-14 and gives much higher $a_{\mathrm{TiO}_{2}}$ values for these three rocks $\left(0.4-0.6\right.$ between 700 and $\left.800{ }^{\circ} \mathrm{C}\right)$. Note also that Perple_X calculates ilmenite contents for two of these granites, unlike rhyolite-MELTS. It is possible that Perple_X systematically overestimates ilmenite stability, because the Ti content of the melt phase is left unconsidered.

\section{$a_{\mathrm{SiO}_{2}}$ values}

The rhyolite-MELTS software program indicates a considerable spread of the $\mathrm{SiO}_{2}$ activity for granites at the onset of magmatic zircon crystallization (Fig. 3b). At 2 kbar, values range from $a_{\mathrm{SiO}_{2}}=1$ in the most $\mathrm{SiO}_{2}$-rich granites to only 0.75 in the least felsic I-type tonalite (number 7 in Table 2). During ongoing magmatic crystallization, i.e., with falling $T, a_{\mathrm{SiO}_{2}}$ approaches unity in all cases. The $a_{\mathrm{SiO}_{2}}-T$ curves at 5 kbar are parallel shifted to slightly higher activity values. The calculation of $a_{\mathrm{SiO}_{2}}$ values with Perple_X gives nearly the same results (see e.g., Fig. 1). 


\section{$a_{\mathrm{TiO}_{2}} / a_{\mathrm{SiO}_{2}}$ net correction effects for Ti-in-zircon thermometry}

As can be seen from Eq. (2), $a_{\mathrm{TiO}_{2}}$ and $a_{\mathrm{SiO}_{2}}$ exert an opposite correction effect on Ti-in-zircon temperatures and it has been speculated that both may widely cancel out in a number of cases (Ferry and Watson 2007). However, according to our calculations, the difference from unity is always much larger for $a_{\mathrm{TiO}_{2}}$ than for $a_{\mathrm{SiO}_{2}}$. Thus, a large net correction generally remains (Fig. $3 \mathrm{c}$ ), although the $a_{\mathrm{TiO}_{2}} / a_{\mathrm{SiO}_{2}}$ net correction will be, in general, a little smaller than the $a_{\mathrm{TiO}_{2}}$ correction alone. According to rhyoliteMELTS, ilmenite-bearing granitic rocks would require a more or less constant $a_{\mathrm{TiO}_{2}} / a_{\mathrm{SiO}_{2}}$ net correction for the Ti-in-zircon thermometer in the order of 0.5. This would correspond to a temperature correction of approximately $+70{ }^{\circ} \mathrm{C}$. According to Perple_X, the $a_{\mathrm{TiO}_{2}} / a_{\mathrm{SiO}_{2}}$ net correction would be in the range of 0.5-0.6 for most granites, equivalent to a temperature correction of approximately $+60{ }^{\circ} \mathrm{C}$ (Table 1). The net corrections for 2 and $5 \mathrm{kbar}$ remain approximately the same, because both $a_{\mathrm{TiO}_{2}}$ and $a_{\mathrm{SiO}_{2}}$ sympathetically increase from 2 to $5 \mathrm{kbar}$ (Fig. 4).

A-type granites and a few special I-type granites may require significantly greater $a_{\mathrm{TiO}_{2}} / a_{\mathrm{SiO}_{2}}$ net corrections for Ti-in-zircon thermometry of between 0.1 and 0.5 , which would correspond to temperature corrections in the order of +100 to $+200{ }^{\circ} \mathrm{C}$.

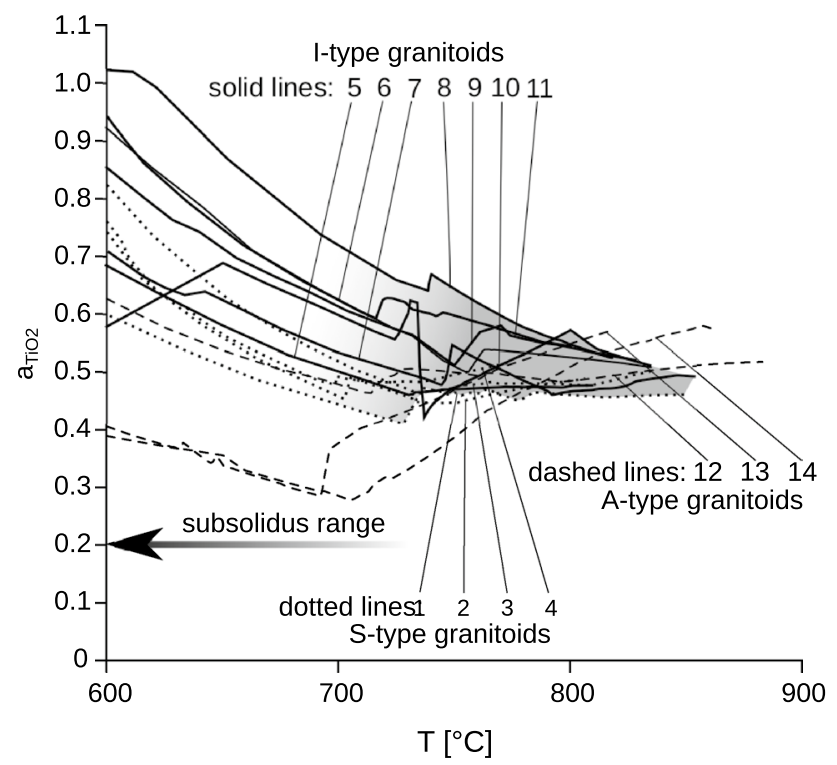

Fig. $4 a_{\mathrm{TiO}_{2}}-T$ functions for the granites from Table 2 calculated with Perple_X. $P=2$ kbar. The following mixing models were used: orthopyroxene, clinopyroxene, biotite, and melt (Powell and Holland 1999); feldspar (Benisek et al. 2010); ilmenite; and magnetite (Andersen and Lindsley 1988)

\section{Discussion}

\section{How reliable are the $a_{\mathrm{TiO}_{2}}$ estimates from rhyolite-MELTS and Perple_X?}

Our calculations with rhyolite-MELTS and Perple_X indicate that zircon crystallization in granites commonly takes place at $a_{\mathrm{SiO}_{2}}$ values of close to 1 and at $a_{\mathrm{TiO}_{2}}$ values of around 0.5 . This would suggest that Ti-in-zircon temperatures for granites have to be significantly upward corrected relative to the original $\mathrm{TiO}_{2}$ - and $\mathrm{SiO}_{2}$-saturated calibration of the thermometer, in the order of $+70^{\circ} \mathrm{C}$. Looking through the literature, we observe that many applications of Ti-in-zircon thermometry to granites so far (including the most recent papers) involved no or only a minor $a_{\mathrm{TiO}_{2}}$ $/ a_{\mathrm{SiO}_{2}}$ correction and could thus bear a significant systematic error (e.g., Sepidbar et al. 2018; Roberts et al. 2018; Chen et al. 2018; Grajales-Nishimura et al. 2018; Langone et al. 2018; Steshenko et al. 2017; Zhang et al. 2018; Shabanian et al. 2017).

The crucial question is, of course, how accurate and reliable are the activity values from rhyolite-MELTS and Perple_X and can they be confirmed by other methods? For instance, Hayden and Watson (2007) have suggested a method for assessing the $\mathrm{TiO}_{2}$ activity of felsic volcanic rocks by comparing the $\mathrm{TiO}_{2}$ content of volcanic glass with that of a rutile-saturated melt (Ryerson and Watson 1987). An analogous approach can be made using the $\mathrm{TiO}_{2}$ contents of rapidly quenched melts from melting experiments on crustal rocks. Gao et al. (2016) present a comprehensive compilation of such data. An evaluation of this data shows that experimentally produced granitoid melts are commonly strongly $\mathrm{TiO}_{2}$-undersaturated in comparison with rutile-saturated melt systems (Hayden and Watson 2007). Most have $\mathrm{TiO}_{2}$ contents that correspond to $a_{\mathrm{TiO}_{2}}$ values of around or just below 0.5 (Fig. 5), and this agrees very well with the rhyolite-MELTS calculations performed in the present paper for a series of granitic rocks.

Most granites do not represent true melt compositions and can contain restitic, peritectic or antecrystic Ti minerals (Clemens and Stevens 2012). Therefore, $a_{\mathrm{TiO}_{2}}$ values are, in general, not deducible from $\mathrm{TiO}_{2}$ whole-rock concentrations. However, in the case of A-type granites 13 and 14 in Table 2, it is obvious from their low $\mathrm{TiO}_{2} / \mathrm{Zr}$ ratios that they must have been severely $\mathrm{TiO}_{2}$ undersaturated at near-liquidus conditions. Thus, the particularly low $a_{\mathrm{TiO}_{2}}$ values of $0.1-0.3$, as calculated by rhyolite-MELTS, are confirmed.

Gualda and Ghiorso (2013) have estimated the activity of $\mathrm{TiO}_{2}$ for a large number of rhyolites and dacites from different volcanic centres, based on mineral chemistry data of coexisting magnetite and ilmenite. Their results show 


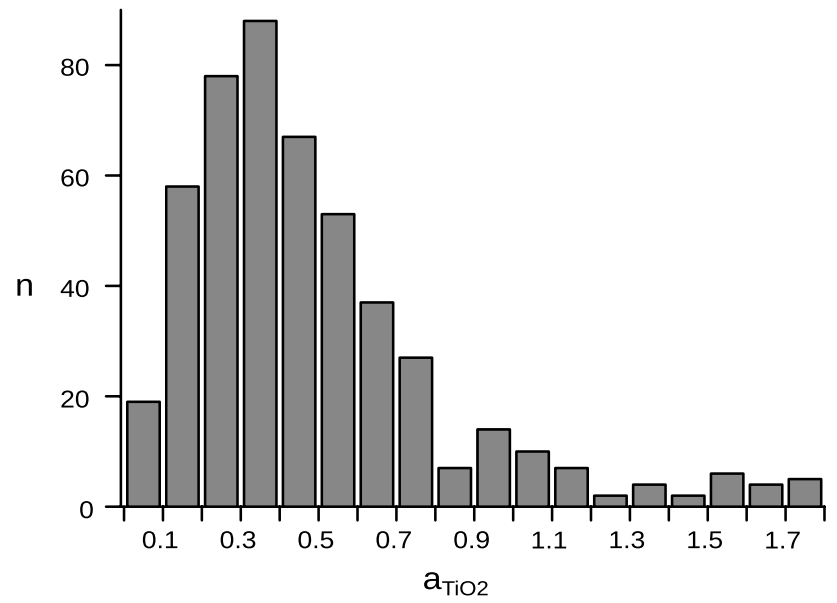

Fig. 5 Histogram of $a_{\mathrm{TiO}_{2}}$ values of experimentally produced granitoid melts. Values were recast from the $\mathrm{TiO}_{2}$ contents of these melts (data source: Gao et al. 2016) in comparison with the $\mathrm{TiO}_{2}$ solubility (Hayden and Watson 2007)

that intermediate $a_{\mathrm{TiO}_{2}}$ values, in the range of $0.5 \pm 0.2$, are very common in felsic magmatic systems. However, examples of volcanic rocks with systematically higher $a_{\mathrm{TiO}_{2}}$ between 0.7 and 0.9 have also been reported. Gualda and Ghiorso (2013) state that such high- $a_{\mathrm{TiO}_{2}}$ magmas are always highly oxidized with oxygen fugacity values well above the Ni-NiO oxygen buffer. For one of these high$a_{\mathrm{TiO}_{2}}$ rocks (the Fish Canyon Tuff-Bachmann et al. 2002), we calculated an $a_{\mathrm{TiO}_{2}}$ value of $\sim 0.7$ for $750{ }^{\circ} \mathrm{C}$ and 0.9 for $650{ }^{\circ} \mathrm{C}$ using Perple_X, which is in good agreement with the Gualda and Ghiorso (2013) values. An attempt to calculate $a_{\mathrm{TiO}_{2}}$ with rhyolite-MELTS failed, because the calculation did not converge at $T<750{ }^{\circ} \mathrm{C}$. The example of the Fish Canyon Tuff shows that certain oxidized rhyolite magmas can crystallize at an $a_{\mathrm{TiO}_{2}}$ of close to 1 . We would expect that intrusive equivalents with similarly high $a_{\mathrm{TiO}_{2}}$ exist as well. However, considering published $\mathrm{Fe}^{3+}$ contents, we tend to believe that such high $f_{\mathrm{O}_{2}}$ and $a_{\mathrm{TiO}_{2}}$ values are only rarely encountered among granites.

In their re-assessment of the Ti-in-zircon thermometer, Ferry and Watson (2007) have proposed that $a_{\mathrm{TiO}_{2}}$ will commonly be between 0.6 and 0.9 in granitic systems. This $a_{\mathrm{TiO}_{2}}$ estimate is a little higher than the values which we received from rhyolite-MELTS and Perple_X. Ferry and Watson (2007) quote two arguments in favor of the 0.6-0.9 $a_{\mathrm{TiO}_{2}}$ range: first, they refer to the work of Ghent and Stout (1984), who calculated $a_{\mathrm{TiO}_{2}}$ close to 1 for amphibolite facies $\left(600{ }^{\circ} \mathrm{C}, 6 \mathrm{kbar}\right)$ metapelitic rocks. However, we argue that the results of Ghent and Stout (1984) are difficult to extrapolate to granite crystallization conditions, because $a_{\mathrm{TiO}_{2}}$ strongly decreases between 600 and $700{ }^{\circ} \mathrm{C}$ (Fig. 4). Therefore, it will be much lower at supra-solidus conditions than at $600{ }^{\circ} \mathrm{C}$. The second argument of Ferry and
Watson (2007) relies on the $\mathrm{TiO}_{2}$ measurements of Hayden and Watson (2007) in rhyolite glasses (as mentioned above). Most of these measurements would indicate $a_{\mathrm{TiO}_{2}}$ values of $0.6-0.8$, but there are also data that correspond to lower $a_{\mathrm{TiO}_{2}}$ of 0.3-0.6. It could be that felsic volcanic systems have, on average, higher $a_{\mathrm{TiO}_{2}}$ values than granites, due to a higher degree of fractionation and higher $f_{\mathrm{O}_{2}}$ (Gualda and Ghiorso 2013).

With respect to the suitability of the rhyolite-MELTS model for the $a_{\mathrm{TiO}_{2}}$ (and $a_{\mathrm{SiO}_{2}}$ ) determination, one aspect may deserve additional discussion: rhyolite-MELTS models orthopyroxene and/or clinopyroxene as major mafic phases of granites and does not properly account for biotite and/ or hornblende crystallization above the solidus, which is definitely a mismatch with nature. Using the Perple_X software, we have investigated whether biotite and hornblende crystallization modifies $a_{\mathrm{TiO}_{2}}$ in a granitic magma relative to orthopyroxene and clinopyroxene parageneses. For instance, Perple_X suggests early ortho-pyroxene crystallization between 850 and $785{ }^{\circ} \mathrm{C}$ and biotite-in at $785{ }^{\circ} \mathrm{C}$ for our sample KV829 (Table 2). Only an insignificant change of the $a_{\mathrm{TiO}_{2}}$ value is recorded at $785^{\circ} \mathrm{C}$ in the $a_{\mathrm{TiO}_{2}}-T$ function (Fig. 1), implying that the presence or absence of biotite vs. orthopyroxene has little effect on the $a_{\mathrm{TiO}_{2}}$. For sample VB198, Perple_X calculates clinopyroxene crystallization at $830{ }^{\circ} \mathrm{C}$ (in the absence of hornblende), whereas hornblende crystallization occurs upon further cooling. The $a_{\mathrm{TiO}_{2}}$ $-T$ function (Fig. 4) shows no major change of $a_{\mathrm{TiO}_{2}}$ at the hornblende-in stage. Therefore, based on these observations we would believe that the general underrating of biotite and hornblende in the rhyolite-MELTS model has no substantial influence on the $a_{\mathrm{TiO}_{2}}$ calculation.

\section{An interesting test case: the Bishop Tuff}

This paper focuses on the application of Ti-in-zircon thermometry in granites, but a consideration of the well known Bishop Tuff in California is informative. The Bishop Tuff belongs to one of the best studied magmatic systems and a wealth of geochemical and mineral chemistry data is available on it, including Ti-in-zircon measurements. We refer, here, to a set of Ti-in-zircon data from the Early Bishop Tuff (eruptive sequence Ig1Eb) published in Chamberlain et al. (2013). This pumice-rich, phenocryst-poor ignimbrite is considered to represent a nearly pure rhyolite melt composition (Hildreth 1979). Various thermometers (Fe-Ti oxides; $\delta^{18} \mathrm{O}$ Qz/Mag; Ti in Qz; Zr solubility) constrain the liquidus-solidus temperature interval to lie between $\sim 750$ and $680{ }^{\circ} \mathrm{C}$ (Fig. 6).

A complication for Ti-in-zircon thermometry is the occurrence of sector-zoned zircons (Chamberlain et al. 2013). A non-stoichiometric incorporation of trace elements is observed in pyramidal zircon sectors (darker tips in CL 


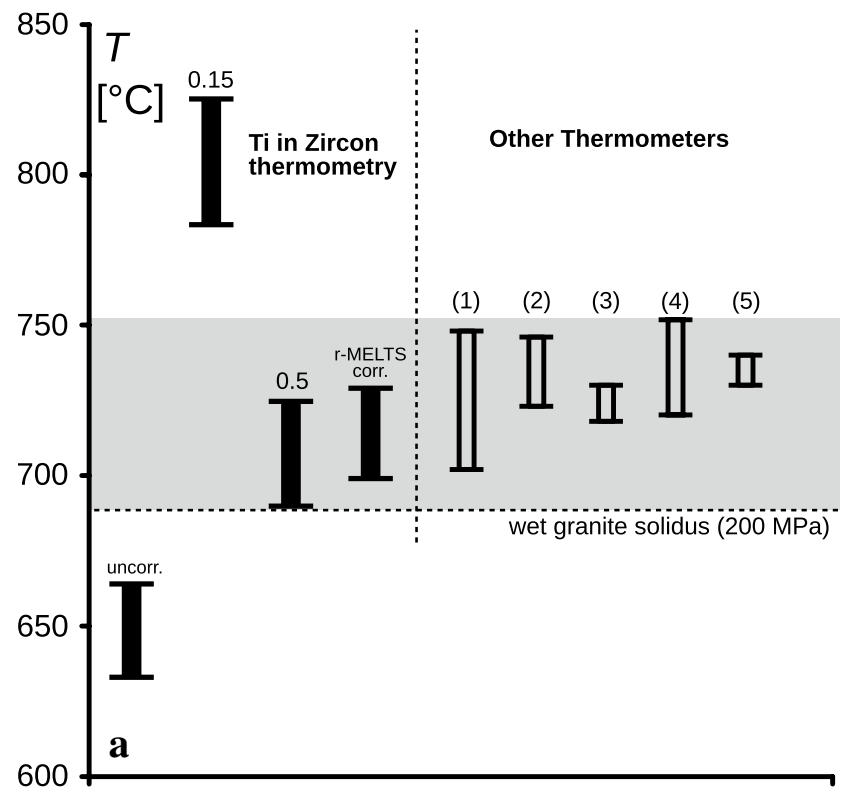

Fig. 6 a Approximate liquidus-solidus temperature interval (grey) of the early Bishop Tuff magma as determined from various geothermometers: (1) Fe-Ti-oxide thermometer on crystal-poor samples of early Bishop Tuff (Hildreth and Wilson 2007). (2) $\delta^{18} \mathrm{O}$ Qz/Mt (eruptive sequence Ig1Ea; Bindeman and Valley 2002). (3) Ti in Qz (eruptive sequence $\operatorname{Ig} 1 \mathrm{~Eb}$; Wark et al. 2007). (4) $T_{\mathrm{Zr}}$ of glass inclusions (early Bishop Tuff; Gualda and Ghiorso 2013). (5) $T_{\mathrm{Zr}}$ (early Bishop

images) indicating disequilibrium growth entrapment of surface impurities (Watson and Liang 1995; Watson 1996). The measured Ti-in-zircon temperatures range from 633 to $664{ }^{\circ} \mathrm{C}$ (uncorrected), excluding these sector zoned tips, which is far below the other estimates of the magmatic crystallization temperatures (Fig. 6). The necessity for an $a_{\mathrm{TiO}_{2}}$ correction to these data has been pointed out by Chamberlain et al. (2013). However, they also emphasize that very different $a_{\mathrm{TiO}_{2}}$ values are published for the rock (0.15-0.63), which would result in extremely different Ti-in-zircon temperatures (Fig. 6).

We calculate $a_{\mathrm{TiO}_{2}}$ values of $0.47 / 0.48$ at $730{ }^{\circ} \mathrm{C}$, and $0.43 / 0.43$ at $700{ }^{\circ} \mathrm{C}$ using rhyolite-MELTS and Perple_X, and the geochemical data of Hildreth (1979). The results confirm our hypothesis that ilmenite-bearing felsic magmas commonly have $a_{\mathrm{TiO}_{2}}$ close to 0.5 . Note that Gualda and Ghiorso (2013) and Reid et al. (2011) calculated similar $a_{\mathrm{TiO}_{2}}$ values of $0.4-0.7$ and $0.53 \pm 0.1$ for the Bishop Tuff from magnetite-ilmenite compositions. Hayden and Watson (2007) have estimated a similar $a_{\mathrm{TiO}_{2}}$ value (0.6) based on $\mathrm{TiO}_{2}$ contents measured in volcanic glass. Thus, for the temperature range of $750-700{ }^{\circ} \mathrm{C}$, all $a_{\mathrm{TiO}_{2}}$ calculations are in good agreement. Figure 6 shows that the rhyolite-MELTSbased activity correction shifts the Ti-in-zircon temperatures into a range that is consistent with other published

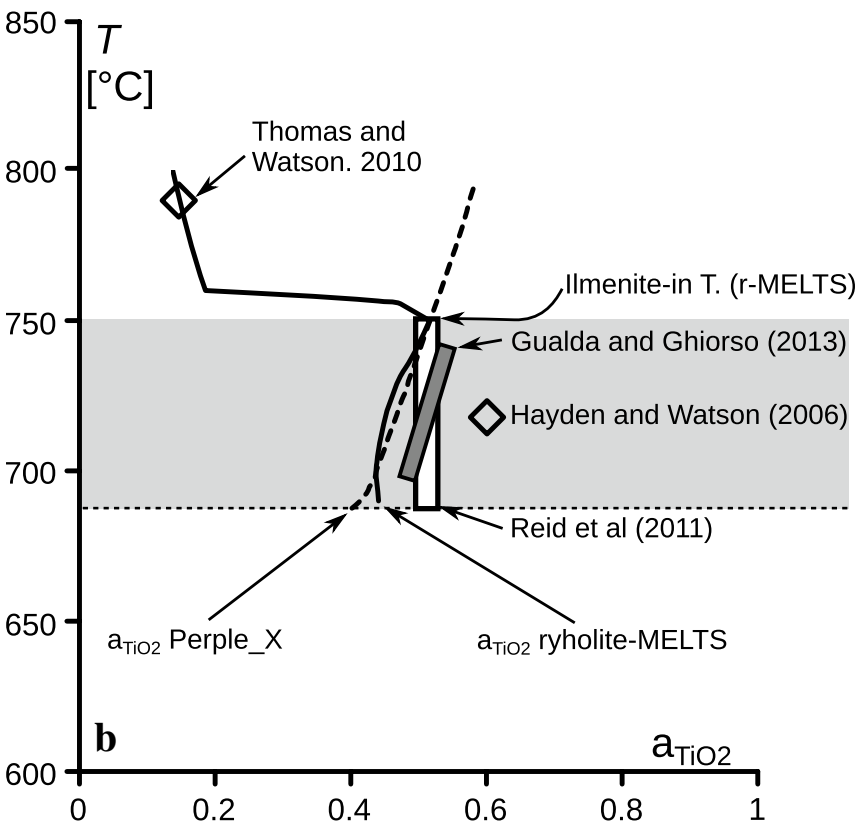

Tuff (Hildreth 1979; Watson and Harrison 1983). Shown for comparison are the results of Ti-in-zircon thermometry (eruptive sequence Ig1Eb; Chamberlain et al. 2013), using various corrections for $\mathrm{Ti}$ activity $\left(a_{\mathrm{SiO}_{2}}\right.$ is assumed to be 1$)$. b Published $\mathrm{TiO}_{2}$-activity data for the Bishop Tuff in comparison to the $a_{\mathrm{TiO}_{2}}-T$ function calculated with rhyolite-MELTS (bold line) and Perple_X (dashed line)

thermometric data. Interestingly, at $T>750{ }^{\circ} \mathrm{C}$, rhyoliteMELTS calculations give significantly lower $a_{\mathrm{TiO}_{2}}$ values, e.g., 0.15 at the calculated liquidus temperature of $780{ }^{\circ} \mathrm{C}$ (Thomas and Watson 2012). We observe a sharp change in the $a_{\mathrm{TiO}_{2}}-T$ behaviour at $\sim 750{ }^{\circ} \mathrm{C}$ (Fig. 6), which coincides with the presence of ilmenite. The absence of ilmenite is calculated by rhyolite-MELTS at $T>750{ }^{\circ} \mathrm{C}$. Calculations using Perple_X do not indicate this strong change in $a_{\mathrm{TiO}_{2}}$. Ilmenite is stable at $T>750{ }^{\circ} \mathrm{C}$, because the Ti content of the melt is not considered. Ilmenite forms phenocrysts in the Late Bishop Tuff. Therefore, $a_{\mathrm{TiO}_{2}}$ values for a ilmenite saturated system must be used for correcting the Ti-in-zircon temperatures. This conclusion is also supported by the fact that a correction with $a_{\mathrm{TiO}_{2}}=0.15$ (the value of Thomas and Watson 2012) would give unrealistically high Ti-in-zircon temperatures (Fig. 6). The example of the Bishop Tuff demonstrates that presence or absence of early ilmenite is an important criterion for making accurate $a_{\mathrm{TiO}_{2}}$ determinations.

\section{Revisiting two other prominent Ti-in-zircon thermometric studies}

In the light of our results, we revisit the work of Fu et al. (2008). They measured Ti contents in zircons from a series of igneous rocks and calculated Ti-in-zircon temperatures 
from these data. Fu et al. (2008) casted fundamental doubts on the validity of the Ti-in-zircon thermometer, arguing that the temperature estimates that they obtained for their samples were, in general, unrealistically low. We limit our comment here to only the data from granitic-tonalitic and rhyolitic-dacitic rocks. Indeed, they quote mean Ti-in-zircon temperatures (uncorrected) for these felsic to intermediate magmatic rocks that appear partly unrealistically low (e.g., $588{ }^{\circ} \mathrm{C}$ in one case). Moreover, single zircon analyses often provided temperature data below the wet granite solidus.

However, assuming that most rocks of granitoid composition crystallize at $a_{\mathrm{TiO}_{2}}$ values of close to 0.5 (or even lower), the Ti-in-zircon temperatures of Fu et al. (2008) would have to be systematically upward corrected by at least $70{ }^{\circ} \mathrm{C}$ and, as such, would approach entirely plausible values. Peak temperature estimates for the rocks would then be between 680 and $900{ }^{\circ} \mathrm{C}$ (considering the $a_{\mathrm{TiO}_{2}}$ correction and the fact that $T_{\text {med }}$ values of Ti-in-zircon thermometry are generally $35-50{ }^{\circ} \mathrm{C}$ below peak magma temperatures). Thus, with regard to the granitoid rocks investigated in Fu et al. (2008), we see absolutely no reason to challenge the Ti-in-zircon thermometer per se. We would rather argue that the data in Fu et al. (2008) confirm the necessity of a significant $a_{\mathrm{TiO}_{2}}$ correction when Ti-in-zircon thermometry is applied to granitoid rocks. We notice, though, that the Ti-in-zircon data of Fu et al. (2008) involve unusually large variations within single zircon populations, resulting in high standard deviations to the average Ti-in-zircon temperatures. Common $T_{\max }-T_{\text {med }}-T_{\min }$ relationships of zircon crystallization should be considerably smaller (Fig. 2), so additional problems seem to be at play. More detailed reanalysis of some of the samples may allow further clarification.

Second, we want to comment briefly on the work of Harrison and Schmitt (2007), who conducted Ti-in-zircon thermometry on the renowned detrital Hadean (i.e., $4.4 \mathrm{Ga}$ old) zircons from Jack Hills/Australia. Application of our standard correction of $a_{\mathrm{TiO}_{2}} / a_{\mathrm{SiO}_{2}}=0.5$ would shift their zircon formation temperatures from $678 \pm 42$ (mean Ti-in-zircon temperature and standard deviation according to Harrison and Schmitt 2007) to $\sim 750{ }^{\circ} \mathrm{C}$ (Carley et al. 2014). Considering in addition the $T_{\operatorname{med}}-T_{\max }$ relationship, the parental magma could have had a peak temperature of closer to $800{ }^{\circ} \mathrm{C}$, which would be absolutely compatible with fluidabsent muscovite and incipient biotite melting in the source rock (Clemens and Vielzeuf 1987). Peak magma temperatures could have been even above $800{ }^{\circ} \mathrm{C}$ if $a_{\mathrm{TiO}_{2}}$ was lower than 0.5 or if the melt was $\mathrm{Zr}$ undersaturated. The contention of Harrison and Schmitt (2007) that these Hadean zircons likely precipitated from a water-saturated low-T silicate melt must thus be challenged.

\section{Conclusions}

Without performing an $a_{\mathrm{TiO}_{2}}$ correction, the application of the Ti-in-zircon thermometer to granitic rocks is presumably too imprecise for providing significant petrological information. To enhance the petrological significance of the thermometer and to reach a high comparability of data, we suggest here that the rhyolite-MELTS software (Gualda et al. 2012) should routinely be used for correcting Ti-in-zircon temperatures for granitoid rocks. It also allows quantifying the (comparably minor) influence of $a_{\mathrm{SiO}_{2}}$. The method appears overall reliable and has the advantage that it is widely applicable, since geochemical data are commonly available (in cases where no $\mathrm{Fe}^{3+}$ data exist, various oxygen buffers can be used in calculation). Rhyolite-MELTS may be preferable to the Perple_X software, because it considers the Ti solubility in melts as well, but both software programs give, in general, comparable results (exceptions are $\mathrm{Ti}$ poor granites where the $\mathrm{Ti}$ is entirely in the melt at near liquidus conditions; for such situations, Perple_X erroneously calculates ilmenite and thus higher $a_{\mathrm{TiO}_{2}}$ values).

A second suggestion for applied Ti-in-zircon thermometry would be to always quote the robust median Ti-inzircon temperature ( $\left.T_{\mathrm{med}}\right)$ of a magmatic zircon population and to model the peak magma temperature based on the ideal zircon crystallization temperature distribution. As a rule, $T_{\text {med }}$ is about $35-50{ }^{\circ} \mathrm{C}$ below the peak magma temperature. Mismatches between the modelled peak magma temperature and the highest measured Ti-in-zircon temperatures must be taken as a hint that complications are at play (Siegel et al. 2018) and the data should be thoroughly reassessed.

We are of the optimistic view that, in the near future, Ti-in-zircon thermometry could achieve the capability to determine the magma temperature of granites with an uncertainty as low as approximately $\pm 20-30{ }^{\circ} \mathrm{C}$, which is roughly twice the calibration uncertainty of the thermometer. To reach this, possible error sources and pitfalls (e.g., uncertainties in the $a_{\mathrm{TiO}_{2}}$ estimation) must be carefully assessed through a number of case studies. These should involve a systematic comparison of Ti-in-zircon temperatures with independent estimations of peak magma temperatures based on $\mathrm{Zr}$ and REE solubility data or other suitable thermometers. However, for granitic systems with low $a_{\mathrm{TiO}_{2}}$, the Ti-in-zircon thermometer could remain generally problematic because of the large influence of the $a_{\mathrm{TiO}_{2}}$ correction.

A persisting uncertainty of the thermometer is the unquantified pressure effect, and experimental work on this field would be highly desirable to further refine the thermometer. The pressure effect may not be as great as 
feared by some authors (Ferry and Watson 2007), based on $\Delta V$ calculations of the $\mathrm{ZrSiO}_{4}$ and $\mathrm{ZrTiO}_{4}$ endmembers. Ti incorporation in zircon is most likely achieved by elastic lattice dilation without any change of the unit-cell volume (Blundy and Wood 1994). As the intrusion depths of most granites are similar, i.e., between 5 and $15 \mathrm{~km}(\sim 2$ to 5 kbar), a relative comparability of Ti-in-zircon temperatures will be given for most granite studies in any case.

When whole-rock data are missing, and for out-of-context zircons, a unified standard correction of $+70{ }^{\circ} \mathrm{C}$ reflecting a ratio of $a_{\mathrm{TiO}_{2}} a_{\mathrm{SiO}_{2}}$ of $\sim 0.5$ may be a first order approximation for Ti-in-zircon thermometry. We believe that this $+70{ }^{\circ} \mathrm{C}$ correction gives good results for ilmenite-bearing granites, which are the most common granites worldwide. It seems better to rely on this simple approach rather than relying on uncorrected Ti-in-zircon temperature data. However, if geochemical data are available for a granite sample, one should always make the effort to determine $a_{\mathrm{TiO}_{2}}$ and $a_{\mathrm{SiO}_{2}}$ values using rhyolite-MELTS, the more so because the procedure is easy and rapid to perform.

Acknowledgements Open access funding provided by Austrian Science Fund (FWF). Careful reviews by Calvin Miller and an anonymous reviewer helped to improve the manuscript. We are grateful to Noreen Vielreicher and Charles Geiger for several stylistic and linguistic advices. This work was supported by the Austrian Science Foundation (Grant number I 1993).

Open Access This article is distributed under the terms of the Creative Commons Attribution 4.0 International License (http://creativeco mmons.org/licenses/by/4.0/), which permits unrestricted use, distribution, and reproduction in any medium, provided you give appropriate credit to the original author(s) and the source, provide a link to the Creative Commons license, and indicate if changes were made.

\section{References}

Alaminia Z, Karimpour MH, Homam M, Finger F (2013) The magmatic record in the Arghash region (northeast Iran) and tectonic implications. Int J Earth Sci 102:1603-1625

Andersen DJ, Lindsley DH (1988) Internally consistent solution models for Fe-Mg-Mn-Ti oxides; Fe-Ti oxides. Amer Miner 73:714-726

Bachmann O, Dungan MA, Lipman PW (2002) The Fish Canyon Magma Body, San Juan Volcanic Field, Colorado: rejuvenation and Eruption of an Upper-Crustal Batholith. J Petrol 43-8:1469-1503

Bateman PC, Chappell BW (1979) Crystallization, fractionation, and solidification of the Tuolumne intrusive series, Yosemite National Park, California. Geol Soc Am Bull 90:465-482

Benisek A, Dachs E, Kroll H (2010) A ternary feldspar-mixing model based on calorimetric data: development and application. Contrib Mineral Petrol 160:327-337

Bindeman IN, Valley JW (2002) Oxygen isotope study of the Long Valley magma system, California: isotope thermometry and convection in large silicic magma bodies. Contrib Mineral Petrol 144(2):185-205

Blundy J, Wood B (1994) Prediction of crystal-melt partition coefficients from elastic moduli. Nature 372:452-454
Boehnke P, Watson EB, Trail D, Harrison TM, Schmitt AK (2013) Zircon saturation re-revisited. Chem Geol 351:324-334

Burke SR (2017) Zircon as proxy for "taking the temperature" of granites: an example using zircon thermometry applied to Greenvillian mid-crustal magmas in the Blue Ridge province, Virginia. Theses and Dissertations-Earth and Environmental Sciences, p 46

Carley TL, Miller CF, Wooden JL, Padilla AJ, Schmitt AK, Economos RC, Bindeman NI, Jordan BT (2014) Iceland is not a magmatic analog for the Hadean: evidence from the zircon record. Earth Planet Sci Lett 405:85-97

Chamberlain KJ, Wilson CJ, Wooden JL, Charlier BL, Ireland TR (2013) New perspectives on the Bishop Tuff from zircon textures, ages and trace elements. J Petrol 55(2):395-426

Chappell BW, White AJR (1974) Two contrasting granite types. Pac Geol 8:173-174

Chappell BW, White AJR, Wyborn D (1987) The importance of residual source material (restite) in granite petrogenesis. J Petrol 28:1111-1138

Chappell B, Bryant C, Wyborn D, White A, Williams I (1998) Highand low-temperature I-type granites. Resour Geol 48:225-235

Chen L, Wang Z, Yan Z, Gong J, Ma S (2018) Zircon and cassiterite $\mathrm{U}-\mathrm{Pb}$ ages, petro-geochemistry and metallogenesis of $\mathrm{Sn}$ deposits in the Sibao area, northern Guangxi: constraints on the neoproterozoic granitic magmatism and related Sn mineralization in the western Jiangnan Orogen, South China. Min Pet 112:447-463

Claiborne LL, Miller CF, Wooden JL (2010) Trace element composition of igneous zircon: a thermal and compositional record of the accumulation and evolution of a large silicic batholith, Spirit Mountain, Nevada. Contrib Mineral Petrol 160:511-531

Clemens J, Stevens G (2012) What controls chemical variation in granitic magmas? Lithos 134-135:317-329

Clemens J, Vielzeuf D (1987) Constraints on melting and magma production in the crust. Earth Planet Sci Lett 86:287-306

Conolly JAD, Petrini K (2002) An automated strategy for calculation of phase diagram sections and retrieval of rock properties as a function of physical conditions. J Metamorph Petrol 20:697-708

Eby GN, Krueger HW, Creasy JW (1992) Geology, geochronology, and geochemistry of the White Mountain batholith, New Hampshire. In: Puffer JH, Ragland PC (Ed) Eastern North American Mesozoic Magmatism. Special Papers-Geological Society of America, vol 268, pp 93-107

Ferry JM, Watson EB (2007) New thermodynamic models and revised calibrations for the Ti-in-zircon and Zr-in-rutile thermometers. Contrib Mineral Petrol 154:429-437

Finger F, Clemens JD (1995) Migmatization and "secondary" granitic magmas: effects of emplacement and crystallization of "primary" granitoids in Southern Bohemia, Austria. Contrib Mineral Petrol 120(3-4):311-326

Finger F, Schiller D (2012) Lead contents of S-type granites and their petrogenetic significance. Contrib Mineral Petrol 164(5):747-755

Finger F, Steyrer HP (1988) Granite-types in the Hohe Tauern (Eastern Alps, Austria)-Some aspects on their correlation to Variscan plate-tectonic processes. Acta Geot 2:75-87

Frasl G, Finger F (1991) Geologisch-petrographische Exkursion in den österreichischen Teil des Südböhmischen Batholiths. Eur J Mineral 3:23-40

Frost BR, Barnes CG, Collins WJ, Arculus RJ, Ellis DJ, Frost CD (2001) A geo-chemical classification for granitic rocks. J Petrol 42:2033-2048

Fu B, Page FZ, Cavosie AJ, Fournelle J, Kita NT, Lackey JS, Wilde SA, Valley J (2008) Ti-in-zircon thermometry: applications and limitations. Contrib Mineral Petrol 156:197-215

Fuchs G, Thiele O (1968) Erläuterungen zur Übersichtskarte des Kristallins im westlichen Mühlviertel und im Sauwald, Oberösterreich: 1:100,000 (Ausgabejahr 1965). Geologische Bundesanstalt, Vienna 
Gao P, Zheng YF, Zhao ZF (2016) Experimental melts from crustal rocks: a lithochemical constraint on granite petrogenesis. Lithos 266:133-157

Gervasoni F, Klemme S, Rocha-Júnior ER, Berndt J (2016) Zircon saturation in silicate melts: a new and improved model for aluminous and alkaline melts. Contrib Mineral Petrol 171(3):21

Ghent ED, Stout MZ (1984) $\mathrm{TiO}_{2}$ activity in metamorphosed pelitic and basic rocks: principles and applications to metamorphism in southeastern Canadian Cordillera. Contrib Mineral Petrol 86:248-255

Ghiorso MS, Gualda GAR (2012) A method for estimating the activity of titania in magmatic liquids from the compositions of coexisting rhombohedral and cubic iron-titanium oxides. Contrib Mineral Petrol 165:73-81

Grajales-Nishimura JM, Ramos-Arias MA, Solari L, MurilloMuñetón G, Centeno-Garcia E, Schaaf P, Torres-Vargas R (2018) The Juchatengo complex: an upper-level ophiolite assemblage of late Paleozoic age in Oaxaca, southern Mexico. Int J Earth Sci 107:1-27

Gualda GAR, Ghiorso MS (2013) The Bishop Tuff giant magma body: an alternative to the Standard Model. Contrib Mineral Petrol 166:755-775

Gualda GA, Ghiorso MS, Lemons RV, Carley TL (2012) RhyoliteMELTS: a modified calibration of MELTS optimized for silicarich, fluid-bearing magmatic systems. J Petrol 53:875-890

Harrison TM, Schmitt AK (2007) High sensitivity mapping of Ti distributions in Hadean zircons. Earth Planet Sci Lett 261(1-2):9-19

Harrison TM, Watson EB, Aikman AB (2007) Temperature spectra of zircon crystallization in plutonic rocks. Geology 35:635-638

Hayden LA, Watson EB (2007) Rutile saturation in hydrous siliceous melts and its bearing on Ti-thermometry of quartz and zircon. Earth Planet Sci Lett 258:561-568

Hildreth W (1979) The Bishop Tuff: evidence for the origin of compositional zonation in silicic magma chambers. Spec Pap Geol Soc Am 180:43-75

Hildreth W, Wilson CJN (2007) Compositional zoning of the Bishop Tuff. J Petrol 48:951-999

Ickert R, Williams I, Wyborn D (2011) Ti in zircon from the Boggy Plain zoned pluton: implications for zircon petrology and Hadean tectonics. Contrib Mineral Petrol 162:447-461

Ishihara S (1977) The magnetite-series and ilmenite-series granitic rocks. Min Geol 27:293-305

Johannes W, Holtz F (1991) Formation and ascent of granitic magmas. Geol Rund 80:225-231

Kemp AIS, Whitehouse MJ, Hawkesworth CJ, Alarcon MK (2005) A zircon U-Pb study of metaluminous (I-type) granites of the Lachlan Fold Belt, southeastern Australia: implications for the high/low temperature classification and magma differentiation processes. Contrib Mineral Petrol 150:230

Kennedy A (2011) New U-Th-Pb isotope reference material for SIMS. Microsc Microanal 17(S2):836-837

King P, White A, Chappell B, Allen C (1997) Characterization and origin of aluminous A-type granites from the Lachlan Fold Belt, southeastern Australia. J Petrol 38:371-391

Klomínský J, Jarchovský T, Rajpoot G (2010) Atlas of plutonic rocks and orthogneisses in the Bohemian Massif. Technical Report TR-01-2010, Czech Geologic Survey; Prague

Langone A, Zanetti A, Daczko N, Piazolo S, Tiepolo M, Mazzucchelli M (2018) Zircon U-Pb dating of a lower crustal shear zone: a case study from the northern sector of the Ivrea-Verbano Zone (Val Cannobina, Italy). Tectonics 37:322-342

Liew TC, Finger F, Höck V (1989) The Moldanubian granitoid plutons of Austria: chemical and isotopic studies bearing on their environmental setting. Chem Geol 76:41-55
Middlemost EAK (1994) Naming materials in the magma/igneous rock system. Earth Sci Rev 37:215-224

Nabelek PI, Russ-Nabelek C, Denison JR (1992) The generation and crystallization conditions of the Proterozoic Harney Peak Leucogranite, Black Hills, South Dakota, USA: petrologic and geochemical constraints. Contrib Mineral Petrol 110(2-3):173-191

Powell R, Holland T (1999) Relating formulations of the thermodynamics of mineral solid solutions; activity modeling of pyroxenes, amphiboles, and micas. Am Miner 84:1-14

Reid MR, Vazquez JA, Schmitt AK (2011) Zircon-scale insights into the history of a Supervolcano, Bishop Tuff, Long Valley, California, with implications for the Ti-in-zircon geothermometer. Contrib Mineral Petrol 161(2):293-311

Rivera TA, Storey M, Schmitz MD, Crowley JL (2013) Age intercalibration of ${ }^{40} \mathrm{Ar} /{ }^{39} \mathrm{Ar}$ sanidine and chemically distinct $\mathrm{U} / \mathrm{Pb}$ zircon populations from the Alder Creek Rhyolite Quaternary geochronology standard. Chem Geol 345:87-98

Roberts NM, Yang Q QY, Santosh M (2018) Rapid oxygen diffusion during high temperature alteration of zircon. Sci Rep 8:3661

Ryerson FJ, Watson EB (1987) Rutile saturation in magmas: implications for $\mathrm{Ti}-\mathrm{Nb}-\mathrm{Ta}$ depletion in island-arc basalts. Earth Planet Sci Lett 86:225-239

Sepidbar F, Mirnejad H, Ma C (2018) Mineral chemistry and Ti in zircon thermometry: insights into magmatic evolution of the Sangan igneous rocks, NE Iran. Chem Erde 78:205-214

Shabanian N, Davoudian AR, Dong Y, Liu X (2017) U-Pb zircon dating, geochemistry and $\mathrm{Sr}-\mathrm{Nd}-\mathrm{Pb}$ isotopic ratios from Azna-Dorud Cadomian metagranites, Sanandaj-Sirjan Zone of Western Iran. Precambr Res 306:41-60

Siégel C, Bryan SE, Allen CM, Gust DA (2018) Use and abuse of zircon-based thermometers: a critical review and a recommended approach to identify antecrystic zircons. Earth Sci Rev 176:87-116

Steshenko E, Nikolaev A, Bayanova T, Drogobuzhskaya S, Chashchin V, Serov P, Lyalina L, Novikov A (2017) The paleoproterozoic Kandalaksha Anorthosite Massif: new U-Pb (ID-TIMS) data and geochemical features of zircon. Doklady Earth Sci 477:1454-1457

Stevens G, Villaros A, Jean-François Moyen JF (2007) Selective peritectic garnet entrainment as the origin of geochemical diversity in S-type granites. Geology 35(1):9-12

Thomas JB, Watson AB et al (2012) Application of the Ti-in-quartz thermobarometer to rutile-free systems. Reply to: a comment on: 'TitaniQ under pressure: the effect of pressure and temperature on the solubility of Ti in quartz' by Thomas et al. Contrib Mineral Petrol 164(2):369-374

Vazquez JA, Kyriazis SF, Reid MR, Sehler RC, Ramos FC (2009) Thermochemical evolution of young rhyolites at Yellowstone: evidence for a cooling but periodically replenished postcaldera magma reservoir. J Volcanol Geotherm Res 188:186-196

Wark DA, Hildreth W, Spear FS, Cherniak DJ, Watson EB (2007) Pre-eruption recharge of the Bishop magma system. Geology 35(3):235-238

Watson EB (1996) Surface enrichment and trace-element uptake during crystal growth. Geoc Cosmoc 24:5013-5020

Watson EB, Harrison TM (1983) Zircon saturation revisited: temperature and composition effects in a variety of crustal magma types. Earth Planet Sci Lett 64:295-304

Watson EB, Liang Y (1995) A simple model for sector zoning in slowly grown crystals: for growth rate and lattice diffusion, with emphasis on accessory minerals in crustal rocks. Am Mineral 80:1179-1187

Watson EB, Wark DA, Thomas JB (2006) Crystallization thermometers for zircon and rutile. Contrib Mineral Petrol 151:413-433

Whalen JB, Currie KL, Chappell BW (1987) A-type granites: geochemical characteristics, discrimination and petrogenesis. Contrib Mineral Petrol 95:407-419 
Whitney DL, Evans BW (2010) Abbreviations for names of rock-forming minerals. Am Miner 95-1:185-187

Williamson BJ, Shaw A, Downes H, Thirlwall MF (1996) Geochemical constraints on the genesis of Hercynian two-mica leucogranites from the Massif Central, France. Chem Geol 127(1-3):25-42

Wyborn D, Turner BS, Chappell BW (1987) The Boggy Plain Supersuite: a distinctive belt of I-type igneous rocks of potential economic significance in the Lachlan Fold Belt. Aust J Earth Sci $34: 21-43$

Žák J, Verner K, Janoušek V, Holub FV, Kachlík V, Finger F, Trubač J (2014) A plate-kinematic model for the assembly of the Bohemian Massif constrained by structural relationships around granitoid plutons. In: Schulman K, Martínez-Catalán JR, Lardeaux JM, Janoušek V, Oggiano G (eds) The Variscan Orogeny: extent, timescale and the formation of the European Crust, vol 405. Geological Society, London, Special Publications, London, pp 169-196

Zhang Y, Shao Y, Liu Q, Chen H, Quan W, Sun A (2018) Jurassic magmatism and metallogeny in the eastern Qin-Hang Metallogenic Belt, SE China: an example from the Yongping $\mathrm{Cu}$ deposit. J Geochem Explor 5:281-297

Publisher's Note Springer Nature remains neutral with regard to jurisdictional claims in published maps and institutional affiliations. 